\title{
Towards solution based thinking: Characteristics of servitization at Hungarian manufacturing companies*
}

\author{
Krisztina Demeter, Levente Szász ${ }^{* *}$
}

The main purpose of the article is to describe the servitization process of Hungarian manufacturing companies based on data of the Hungarian Competitiveness research. Servitization aims at supplying a bundle of products and services that offers complete solutions for customers. In this paper we analyze to what extent characteristics of servitization in developed countries are also applicable in a developing macro-environment, i.e. in Hungary. Results of our analysis show that, generally, Hungarian manufacturing companies do not place strategic emphasis on services. Nevertheless, our sample contains a number of manufacturing companies that have taken actions to servitize both on strategic and operational level. However, in case of these companies financial benefits attributable to higher levels of servitization do not yet seem to materialize.

Das Hauptziel dieses Artikels ist den Prozess des Kundenservices von ungarischen produzierenden Unternehmen zu beschreiben, basierend auf der ungarischen Wettbewerbsforschung. Der Kundenservice zielt auf die Bereitstellung eines Bündels von Produkten und Dienstleistungen ab, das den Kunden komplette Lösungen anbietet. In diesem Artikel wird analysiert in welchem Maße Aspekte des Kundenservices in entwickelten Ländern auf Transformationsländer wie Ungarn anwendbar sind. Die Ergebnisse unserer Analyse zeigen, dass im Allgemeinen produzierende Unternehmen in Ungarn ihren strategischen Schwerpunkt nicht auf Dienstleistungen legen. Dennoch enthält unsere Stichprobe eine Reihe von produzierenden Unternehmen, die in dieser Hinsicht Maßnahmen ergriffen haben, sowohl auf strategischer als auch auf operativer Ebene. Jedoch scheinen im Falle dieser Unternehmen finanzielle Vorteile, die auf ein höheres Level von Kundenservice zurückzuführen sind, noch nicht wirklich greifbar zu geworden sein.

Keywords: servitization, integrated solutions, operations strategy, financial performance

\footnotetext{
Manuscirpt received: 29.04.12, Accepted: 16.11 .12 (1 Revision)

** Krisztina Demeter, PhD, Corvinus University of Budapest, Institute of Business Economics, Logistics and Supply Chain Management Department. Research interests: operations strategy, servitization, global operations

Levente Szász, PhD, Babes-Bolyai University, Faculty of Economics and Business Administration. Research interests: operations strategy, servitization, supply chain management
} 


\section{Introduction}

Our paper focuses on the servitization of manufacturing companies. Servitization denotes the process by which the output of manufacturing companies is shifting from delivering pure physical products towards offering a bundle of products and services. Pressures from competitors and customers determine more and more manufacturing companies to choose the path of servitization. The intense competition on product markets and the sophistication of customer expectations push manufacturing companies toward providing integrated solutions for their customers instead of simply selling physical commodities (Mathieu 2001; Alonso-Rasgado et al. 2004; Tuli et al. 2007). Solution-based thinking requires that more and more service elements are added to the core product of manufacturing companies (e.g. Matthyssens/Vandenbempt 2008, Reinartz/Ulaga 2008).

The term "servitization" was first used in the international literature by Vandermerwe and Rada (1988). While service management and marketing scholars did not use the term itself, they also identified the same phenomenon. Grönroos (1990), for example, argues that the vast majority of manufacturing companies build services into their packages provided to customers. Referring to the macro level, Evans and Berman (1987) use the term of "hidden service sector" arguing that a significant portion of services in an economy is provided by manufacturing companies, which is not documented in official statistics. Starting from the early ' 90 s several papers have been focusing on the servitization of manufacturing companies. These studies have primarily dealt with defining the concept of servitization and its major forms, identified the main drivers and barriers of servitization, and offered several methods to overcome these barriers (Baines et al. 2009). More recently, literature places higher emphasis on researching macro and micro level factors that may affect servitization. These papers, however, focus mainly on developed countries, and are usually based on case studies (Baines et al. 2009).

In contrast with previous studies, our article aims to bring two important contributions to the literature. First, the empirical part of our research relies on a large database of manufacturing companies, enabling us to test previous servitization related results on a more general level. Second, we also aim to study servitization related premises, generally accepted in the international literature, but placing them in a different macro environment (i.e. in a developing country). Therefore, the data employed in our empirical research refers exclusively to manufacturing companies operating in the developing economy of Hungary.

The article is structured as follows. First, we introduce the main propositions and assumptions of the international servitization literature that are related to our study, and formulate research hypotheses accordingly. Next, the characteristics 
of our data sample and the applied research methodology are described which are used to test our hypotheses. After analyzing the data and evaluating the results we draw our conclusions.

\section{Literature review and hypotheses}

The main objective of our paper is to study servitization in a macro-environment that is different from those used by the majority of previous studies. The relationship between various factors of macro level economic development (e.g. intensity of competition, level of technological development, infrastructural development, level of education and training, labour market efficiency, etc.) and servitization is accepted or partly accepted by many authors (e.g. Chase/Garvin 1989; Cohen et al. 2006; Davies 2004; Gebauer et al. 2005). However, these assumptions are rarely based on an analysis of large databases containing widespread company-level data. One exception is Neely's (2008) study, which analyzes the characteristics of servitization and its financial consequences based on data from 25 countries and 10000 companies. The study draws the conclusion that "the servitization of manufacturing is clearly influenced by ... local economic circumstances ... there tend to be more manufacturing firms that have servitized in highly developed economies than in industrialising economies" (Neely 2008: 113-114). However, these results do not apply universally. There are several developed countries (e.g. Austria, France, Japan) that do not fit the argument (Neely 2007). Knowing these apparently inconsistent results, Hungarian data might provide valuable insight.

Based on the general assumption used in international studies we could assume, that servitization is not yet widespread among Hungarian companies. However, the results of a previous Hungarian study, where manufacturing seems to be more service oriented than service companies themselves, do not entirely support this view (Demeter 2009). Thus, the commitment of Hungarian companies to servitization is still an open question. In our study we propose to analyze servitization of Hungarian manufacturers from three different perspectives:

- Strategy: what is the role of services in the operations strategy of manufacturing companies?

- Operations: what practical efforts do manufacturing companies make to servitize?

- Business performance: can manufacturing companies with higher service focus generate higher financial results? 


\section{Strategy}

Literature provides clear explanation for the relationship between servitization and business strategy. One of the most important roles of business strategy is to create competitive advantage for the firm (Chikán 2008). The argument behind the servitization trend of manufacturing companies is similar: under the circumstances of a continuously increasing market competition it is more and more difficult for manufacturing companies to maintain product-based competitive advantages (such as technological advantage, low-cost manufacturing or wide product variety). In such a competitive environment services - offered alongside the core product - can become a source of sustainable competitive edge (Grönroos 1990; Oliva/Kallenberg 2003). Adding services to products and thereby offering integrated solutions for customers can serve as a differentiating factor, considerably improving the competitiveness of firms (Grönroos 1990; Frambach et al. 1997; Gebauer/Fleisch 2007). Frambach et al. (1997), for example, highlight that services add important customer value to the product; thus, customers can perceive even homogenous physical commodities as customized products. Service-based competitive advantage can be more sustainable, because it is less "visible", less tangible, more labour intensive, and, thus, more difficult for competitors to imitate (Oliva/Kallenberg 2003).

However, the positive impact of servitization on competitiveness can only be achieved by developing a service and customer oriented strategy (Vandermerwe/Rada 1988). While in the past company managers usually considered product related services as a necessary evil (Wise/Baumgartner 1999), efficient servitization requires that the importance of services is raised to a strategic level (Baines et al. 2009). For truly successful service-based strategies services should appear as differentiating factors and become a major source of customer value creation, shifting companies towards solution-based thinking (Vandermerwe/Rada 1988; Pawar et al. 2009).

Briefly, servitized manufacturing companies can be identified by having operations strategies that place a higher emphasis on services relative to other competitive factors. In these cases services should become a source of competitive advantage. However, in less developed countries, like Hungary, the macroeconomic environment does not provide adequate background to pursue a service based manufacturing strategy (Neely 2008). We formulate our first hypothesis in accordance with this argument.

H1: Hungarian manufacturing companies do not place a higher strategic emphasis on providing services relative to the strategic importance of other sources of competitive advantage. 
It is important to note that in $H 1$ we do not argue that services may not become order winner factors (Hill 1993) at some Hungarian manufacturing companies, but we hypothesize instead that on average services are not likely to play a more important strategic role than other competitive factors, like quality, price, volume flexibility or product variety. Besides assuming that Hungarian companies do not generally stress the importance of services in their manufacturing strategies, we also expect that the importance of services has not increased significantly in the last years in comparison with other potential sources of competitive advantage. Thus, the first hypothesis can be broken down into the following two parts.

H1a. Within the operations strategy of Hungarian manufacturing companies services do not have higher strategic importance on average, relative to other sources of competitive advantage.

H1b. In the last years services did not have a higher increase in strategic importance relative to other sources of competitive advantage.

\section{Operations}

Besides analyzing services on a strategic level we also examine the extent to which manufacturing companies deal with services at operational level during their day-to-day efforts. Offering integrated solutions for customers demands significant changes in everyday company operations. To offer integrated solutions for customers servitized manufacturing companies have to simultaneously focus on manufacturing products and on providing different types of services, like financial services, maintenance and repair, consultancy or training (Davies et al. 2006). However, to efficiently provide these services, companies have to overcome several barriers in their day-to-day operations (Brax 2005). These challenges include the following operational factors:

- In marketing and sales operations servitizing companies cannot focus exclusively on increasing product sales; they also have to provide continuous support for the sale of services (Kindström/Kowalkowski 2009).

- Servitization represents a communication challenge, since customer feedbacks have to be used more frequently and more intensively to improve services and provide real solutions to customer problems. Closer interaction is needed to define customer needs clearly, to implement and support the solution and, afterwards, to evaluate the services provided (Tuli et al. 2007; Lindberg/Nordin 2008). In order to overcome this barrier companies need to have an appropriately trained personnel and developed communication channels.

- Companies have to apply changes in product manufacturing: providing after-sales/supporting services means that the technological and 
operational risk is not wholly transferred to the customer. The manufacturer remains responsible for efficient product functioning throughout the whole product life-cycle (Oliva/Kallenberg 2003). Thus, manufacturers have to obtain detailed and up-to-date information regarding the everyday use of products sold. Then, they need to use these data in manufacturing to produce more reliable products.

- In product design the adoption of new technologies is needed to ease the everyday use of products and make after-sales services easier to manage/offer. Several authors argue that the high level of technological development is an important prerequisite of servitization (Chase/Garvin 1989; Neely 2008). Servitization literature offers several case study examples of high technology systems (e.g. remote controlled machine maintenance systems, integrated operational-financial systems, innovative delivery systems, IT solutions for intercompany information exchange) that are necessary for efficient servitization (Davies 2004; Johnson/Mena 2008; Schmenner 2009).

- When choosing the path of servitization manufacturing companies get in much closer contact with their customers than during their traditional manufacturing operations (Wise/Baumgartner 1999; Oliva/Kallenberg 2003). This shift forces manufacturing companies to change their customer relationship management practices and to employ a more relationship-oriented model instead of the more classic, transaction-based one, to keep closer contact with customers (Gulati/Kletter 2005; Bastl et al. 2009). Understanding and clearly defining the needs of customers is considered a key element of successful solution providing (Tuli et al. 2007).

To overcome the operational challenges listed above, companies have to employ a highly qualified, flexible labour force instead of having employees that work exclusively in manufacturing. This change in human resource management is one of the most important preconditions of moving toward a customer focused, relationship-based business model (Chase/Garvin 1989; Brax 2005; Raja et al. 2010). Employing highly qualified labour force and developing closer cooperation with customers are crucial elements not only in service provision (Correa et al. 2007), but also in the new service development process (Johne/Storey 1998; Matthing et al. 2004; Kindström/Kowalkowski 2009).

Starting from the identified challenges of servitization and from the operational changes required to overcome these challenges, we assume that Hungarian manufacturing companies place lower emphasis on carrying out projects and activities than the level that would help to efficiently overcome these barriers. Thus our second hypothesis is the following: 
H2. On average, Hungarian manufacturing companies do not place a higher emphasis on implementing service related action programmes related to other types of action programmes.

The first two hypotheses assume, on average, a low level of servitization both from strategic and operational perspective. However, building on Neely's (2008) study, the possible existence of certain groups of more intensively servitized companies is also worth examining.

Based on a large-scale international database Neely (2008) found that besides the level of economic development, company size may also affect servitization. Thus, we expect that in Hungary larger companies use servitization more frequently than other companies.

H3a. In Hungary large manufacturing companies use servitization more intensively than small and medium sized companies.

If we accept that servitization appears more frequently in developed economies (Neely 2008), we may also assume that companies with foreign majority ownership in Hungary are more likely to choose the path of servitization. Relying on their experiences in servitization earned abroad, they could more easily turn to servitization and overcome its barriers more efficiently.

$\mathrm{H} 3 \mathrm{~b}$. In Hungary foreign majority owned companies use servitization more intensively than other companies.

Similarly, we may also assume that Hungarian manufacturing companies being more present on international markets and selling their products globally are more likely to servitize. On the one hand, they might have to compete with companies that use servitization more intensively (Neely 2008), and, on the other hand, they might face more sophisticated and complex customer needs (Brax 2005; Kindström/Kowalkowski 2009).

H3c. In Hungary manufacturing companies being more present on global markets with their products and services use servitization more intensively than other companies.

Lastly, the position of Hungarian manufacturing companies in the value chain has also to be controlled for, since it might have an impact on servitization. Many authors ascertain that servitization of manufacturing originates from customer needs becoming more and more sophisticated (Brax 2005; Kindström/Kowalkowski 2009). Moreover, servitization literature largely focuses on cases where services and integrated solutions are provided directly to end-consumers (Lay et al. 2010). Therefore, we may assume that more downstream companies, i.e. those positioned closer to their end-consumers in the value chain (Wise/Baumgartner 1999; Baines et al. 2011) are more likely to servitize. 
H3d. Hungarian manufacturing companies being in a more direct relationship with the end-consumers of their products use servitization more intensively than other companies.

\section{Business performance}

Servitization can become a differentiating factor among manufacturing companies not only at the strategic level, but it can also lead to significant financial advantages (Baines et al. 2009). Services provided with products can increase product sales and contribute to market share growth (Mathe/Shapiro 1993; Mathieu 2001). Moreover, they can generate a higher and more stable revenue stream, coupled with higher profit ratios (Wise/Baumgartner 1999). Services connected to products create higher customer value, which can also contribute to customer loyalty and, thus, to future sales growth (Heskett et al. 1997; Correa et al. 2007).

In our study we investigate if companies with higher levels of servitization can achieve higher financial results, i.e. generate higher sales, increase market share and improve profit ratios. Although previously cited studies highlight the financial advantages of servitization, the relationship between servitization and financial performance is not that simple. Gebauer et al. (2005) present several case study companies that invested a significant amount of resources into developing and providing services, but the expected financial results were not achieved. Authors describe this phenomenon as the "service-paradox". According to them, the service-paradox can be traced back to intra-company factors and barriers. Subsequent studies, however, suggested that inter-company factors may play an equally important role (Windahl/Lakemond 2006; Bastl et al. 2012). These barriers and the lack of response to these barriers is the main reason of why companies cannot realize the expected financial benefits of servitization. In spite of these facts, in our research we assume that higher level of servitization should generally result in higher financial performance. Thus, our fourth hypothesis is the following:

H4. In Hungary manufacturing companies with higher servitization level achieve higher financial performances than other manufacturing companies.

\section{Research design}

We aim to test our research hypotheses based on the fourth round of the Hungarian Competitiveness Survey, carried out in 2009. The Competitiveness Survey is a questionnaire based survey started in 1996 at the Institute of Business Economics of the Corvinus University of Budapest, led by professor Attila Chikán. The primary objective of the research at that time was to analyze the microeconomic foundations behind the macroeconomic performance of the Hungarian industry. During the four rounds of the Competitiveness Survey 
researchers were able follow the characteristics of economic transition, could discover its barriers and the drivers of success, or the key challenges of accessing the EU (see, e.g. Balaton 2005). The main results of each round of the Hungarian Competitiveness Survey were summed up in several books and research reports (Chikán et al. 1996, 2002; Chikán/Czakó, 2009). Due to the successful development of the research program in the past years, it already has an own research centre, making results widely accessible via its website (www.vallgazd.hu).

The fourth round of Hungarian Competitiveness Survey had 313 participating companies, 127 of them belonging to various manufacturing industries ( $41 \%$ of the total sample). Since servitization focuses on manufacturing companies, we use only this latter portion of the sample. The distribution of our sample by industries is described in Table 1.

Table 1: Industrial structure of the research sample

\begin{tabular}{|l|c|c|}
\hline Industry & Company & \% of total \\
\hline Food industry & 20 & $15.7 \%$ \\
\hline Light industry & 13 & $10.2 \%$ \\
\hline Chemical industry & 14 & $11.0 \%$ \\
\hline Machinery and equipment & 44 & $34.6 \%$ \\
\hline $\begin{array}{l}\text { Other manufacturing } \\
\text { industries }\end{array}$ & 36 & $28.3 \%$ \\
\hline Total & $\mathbf{1 2 7}$ & $\mathbf{1 0 0 \%}$ \\
\hline
\end{tabular}

We have to note here, that the sample of Hungarian manufacturing companies used in our study (Table 1) is not statistically representative for the whole Hungarian manufacturing industry. Still, the number of different industries included in our study, and the diversity of companies in our sample in respect of size and ownership enables us to draw some more general conclusions. However, special care has to be taken in formulating our conclusion, restricting its generalizability to our research sample.

In respect of the research methods used, we mostly applied t-tests and analysis of variance (ANOVA) to investigate differences between various sub-groups of our sample. In cases where the preliminary test of homogeneity of variances indicated that the results are not necessarily reliable, we also used the Welch and the Brown-Forsythe robust test of equality of means to double-check our results and strengthen their statistical validity.

In the next section, using the sample of 127 Hungarian manufacturing companies presented in Table 1, we analyze the characteristics of servitization from a strategic, operational and business performance perspective. 


\section{Empirical analysis and findings}

\section{Strategic perspective}

To test our first hypothesis, we first analyzed the strategic importance of services at Hungarian manufacturing companies relative to other potential competitive priorities. Scientific literature identifies several competitive dimensions (termed as competitive priorities) which enable manufacturing companies to win orders from customers and to succeed in market competition by delivering better performance than the main competitors (Hill 1993). The 11 categories of competitive priorities used in our study refer to one of the following broad competitive factors: cost/price, quality, order fulfilment, services, flexibility, innovation and environmental protection (Hayes/Wheelwright 1984; Leong et al. 1990; Miller/Roth 1994; Ward et al. 1998; de Burgos Jimenez/Cespedes Lorente 2001). Companies had to indicate the importance of these strategic factors on a 1-5 Likert scale, where a higher score indicates higher strategic priority. Average importance scores and the difference of each competitive priority relative to the importance of services (paired-samples t-tests) are shown in Figure 1.

Figure 1: Average strategic importance of competitive priorities

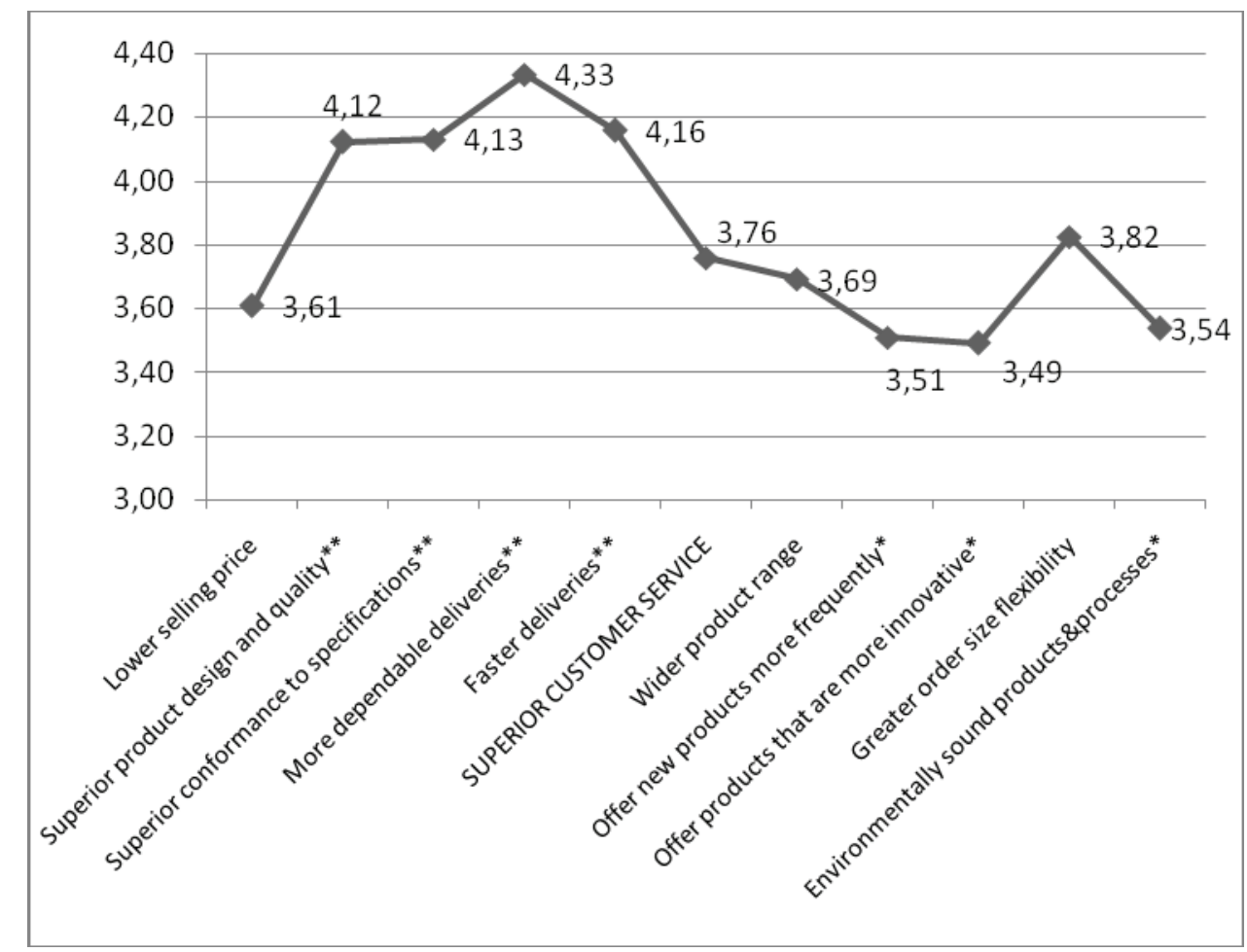

The difference between "Superior customer service" and a given competitive priority is significant at: $* * \mathrm{p}=0.01$ level, $* \mathrm{p}=0.05$ level

According to these results, customer service is not among the top priorities of Hungarian manufacturing companies. The most important competitive priorities are quality ("Superior product design and quality" and "Superior conformance to specifications") and order fulfilment ("More dependable deliveries" and "Faster 
deliveries"), both being significantly more important than customer service (paired-samples t-test on $\mathrm{p}=0.01$ level). However, at this point we have to note that in many cases customer service is used in a tighter meaning in Hungary as well, and usually refers only to the handling of customer complaints. This tighter meaning could also contribute to the lower importance of services relative to the most important competitive priorities (quality and order fulfilment). On the other hand, servitization is considered a much broader term, including for example financial services that make product purchasing easier, maintenance services, or consultancy services. Although servitization covers a broad variety of services, from our perspective customer service can be considered as an appropriate substitute. International literature also supports that customer service (in the meaning of handling customer complaints) is a necessary precondition for companies intending to provide services alongside their products (Oliva/Kallenberg 2003; Gebauer et al. 2005); i.e. if a company scores low on customer service it cannot score high on servitization. Furthermore, the term "customer service" can be used and understood in its wider meaning (Stock/Lambert 2001), as a company philosophy that aims at providing complete solutions for customers (Davies et al. 2006; Matthyssens/Vandenbempt 2008). Consequently, in the following sections we are not going to make any difference between the meaning of customer service and providing a variety of services for customers.

Comparing the mean absolute importance of competitive priorities (Figure 1) offers a relevant picture about the strategic intent of Hungarian manufacturing companies. However, in order to analyze Hla (which refers to the importance of services related to other competitive priorities) we also have to determine the relative importance of services for each individual company. This is an essential step, because the true strategic importance of services can only be understood if it is compared to the importance of other competitive priorities at each company. For this purpose we determined the ratio of the absolute importance of services, on one hand, and the average importance of all other competitive priorities, on the other hand. In the following this ratio will be referred to as the relative importance of services. Using this measure we can more precisely differentiate companies that assign a prominent role to services from those that do not view services as a strategically important competitive priority (we will use this differentiation to test $H 3 a, H 3 b, H 3 c, H 3 d$ and $H 4$, as well). A value the relative measure greater than 1 indicates that services play a more important role than other competitive priorities at a given manufacturing company, while a value lower than 1 indicates that the company does not consider services strategically important. The distribution of the relative importance measures of services in the sample is described by Figure 2. 
Figure 2: The distribution of the relative importance measures of services

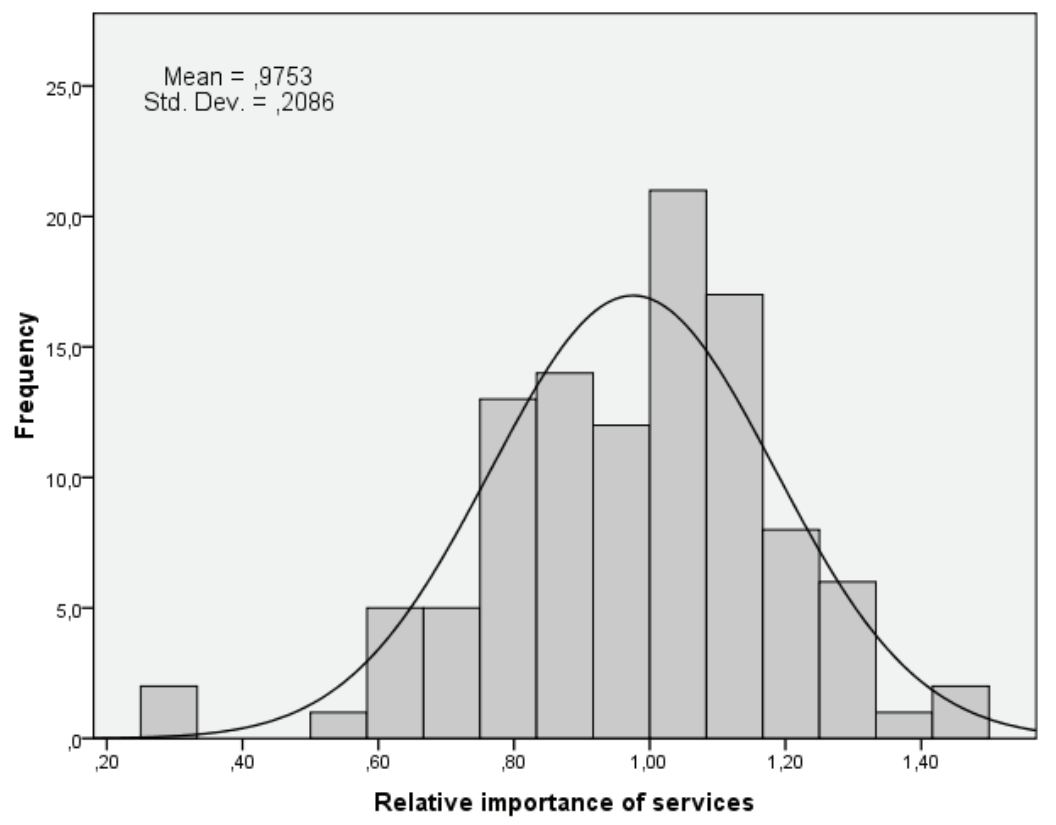

Figure 2 shows that the relative importance measures of services follow a normal distribution pattern (Kolmogorov-Smirnov test, $p=0.200$, Shapiro-Wilk test, $\mathrm{p}=0.152$ ). Consequently, we can find manufacturing companies in our sample that assign a high strategic importance to services, but there are also several other companies that hardly place any strategic importance on services. On average, services are confirmed not to have an outstanding position among competitive priorities: the mean value of relative importance measures of services is 0.9753 , which does not differ significantly from 1 (one-sample t-test with test value $=1, \mathrm{p}=0.224$ ). Thus, Hla can be accepted.

While our results confirm that on average services do not play an outstanding role in the operations strategy of Hungarian manufacturing companies, the distribution of relative importance measures shows that there are still several manufacturers that consider services strategically important. Therefore, differences between the strategies of servitized and less servitized companies might also be relevant to examine. In order to do this we divided our sample into two groups:

- "Servitized companies", where the relative importance of services is $>1$ (47 companies)

- "Traditional manufacturers", where the relative importance of services is $\leq 1$ (54 companies)

We examined if there is any significant difference between the two groups in terms of the relative importance of other competitive priorities (ANOVA). Results are summarized in Table 2. 
Table 2: Differences between servitized companies and traditional manufacturers in terms of their strategic priorities

\begin{tabular}{|l|c|c|c|}
\hline \multicolumn{1}{|c|}{ Competitive priority } & $\begin{array}{c}\text { Servitized } \\
\text { companies }\end{array}$ & $\begin{array}{c}\text { Traditional } \\
\text { manufacturers }\end{array}$ & Sig. \\
\hline Lower selling prices & 0.889 & 0.992 & 0.016 \\
\hline Superior product design and quality & 1.050 & 1.108 & 0.070 \\
\hline $\begin{array}{l}\text { Superior conformance to customer } \\
\text { specifications }\end{array}$ & 1.064 & 1.094 & 0.362 \\
\hline More dependable deliveries & 1.102 & 1.169 & 0.064 \\
\hline Faster deliveries & 1.065 & 1.106 & 0.281 \\
\hline Wider product range & 0.963 & 0.952 & 0.775 \\
\hline Offer new products more frequently & 0.905 & 0.915 & 0.820 \\
\hline $\begin{array}{l}\text { Offer products that are more } \\
\text { innovative }\end{array}$ & 0.894 & 0.911 & 0.667 \\
\hline Greater order size flexibility & 0.978 & 1.022 & 0.208 \\
\hline $\begin{array}{l}\text { Environmentally sound products and } \\
\text { processes }\end{array}$ & 0.937 & 0.899 & 0.387 \\
\hline
\end{tabular}

* The difference is significant at $\mathrm{p}=0.05$ level

According to these results the only significant difference between the two groups is in the strategic role of selling prices, which is in concordance with the literature. Since services offered with products usually increase the total value of the output package, together they can be sold more expensively (Heskett et al. 1997; Correa et al. 2007; Gebauer/Fleisch, 2007). Hence, servitized companies can rarely enter a price-based competition, and, therefore, they assign a lower relative importance to selling prices in their operations strategy.

To test $H 1 b$, the previously used static perspective of competitive priorities has to be replaced by a dynamic one, which considers the evolution in time of the strategic importance of competitive factors. In the questionnaire respondent companies had to indicate on a 1-5 point scale to what extent the strategic importance of various competitive factors has improved or deteriorated in the last three years. The discrete values of the scale indicate the following importance changes:

- 1: decreased by more than $5 \%$,

- 2: remained approximately the same, $-5 \% /+5 \%$,

- 3: improved by $5-10 \%$,

- 4: improved by $10-25 \%$,

- 5: improved by more than $25 \%$.

Average changes in importance of competitive factors are indicated in Figure 3. 
Figure 3: Level of importance change in competitive priorities over the last three years

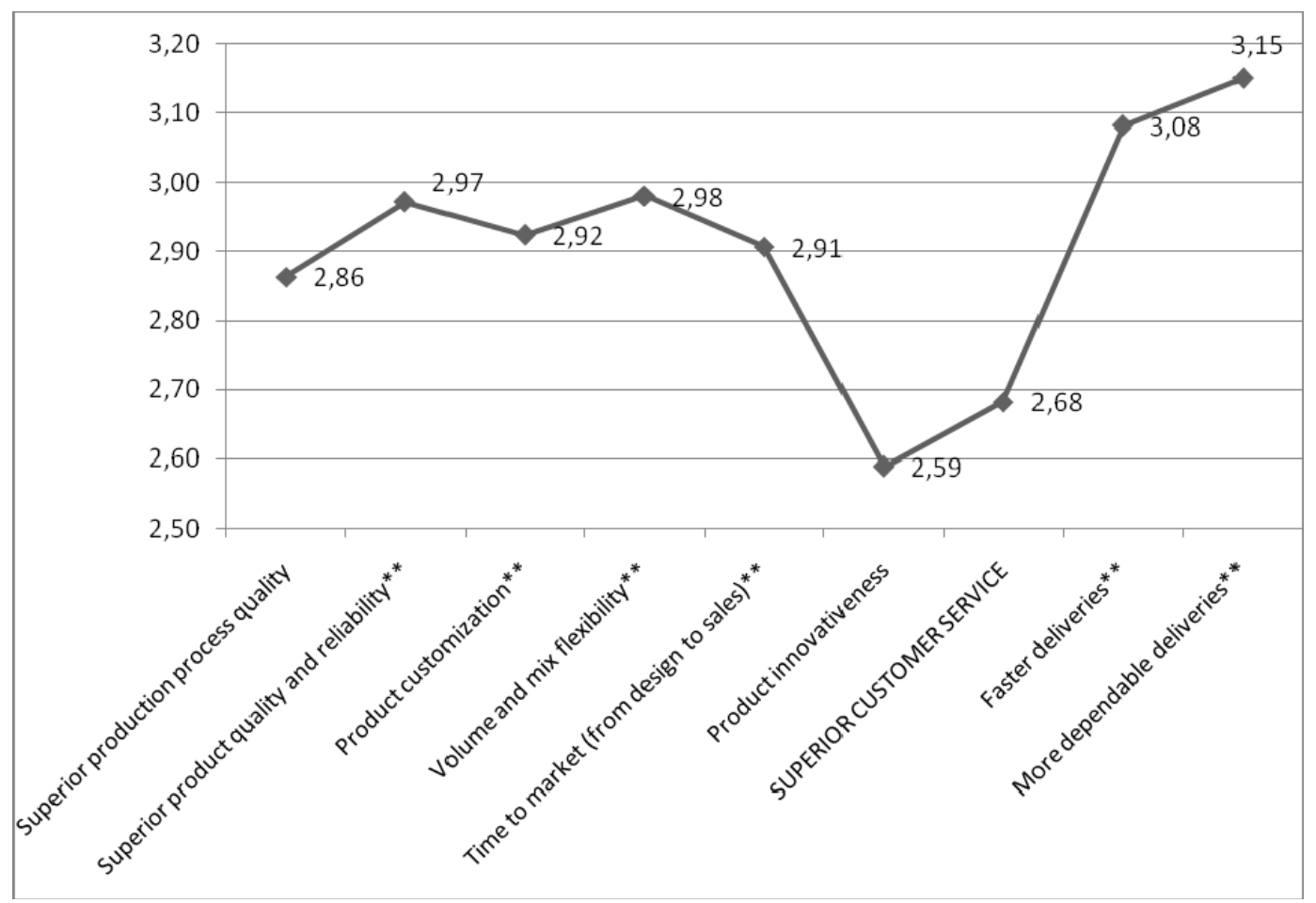

**The difference between the change in importance of a certain competitive priority and "Superior customer service" is significant at $\mathrm{p}=0.01$ level

Based on Figure 3, we found that the strategic role of services has definitely not increased more than the importance of other competitive priorities in the last three years (paired-samples t-tests on $\mathrm{p}=0.01$ level). Customer services are on the penultimate place in the list of priority improvements. Results of the pairedsamples t-tests show that the strategic importance of services has increased less than the following competitive priorities: product quality and reliability, product customization, volume and mix flexibility, time to market (from design to sales), product innovativeness, faster deliveries, more dependable deliveries. Similarly low levels of improvement can be observed only in case of product innovativeness and superior production process quality. However, on $p=0.1$ level this latter priority has also a significantly higher increase in strategic importance than customer services. In summary, $H 1 b$ hypothesis can be accepted.

\section{Operational perspective}

The Competitiveness Survey used in our study included questions about the use of several action programs, which represent adequate tools and methods to overcome the barriers and challenges of servitization, presented in the literature review. Among these action programs we focus our attention on two certain dimensions that can play a crucial role in overcoming the barriers of servitization: 
- Developing new services, and the role of technology in new service development,

- Developing organizational capabilities that help companies shifting from a transaction oriented model towards a relationship-based model.

To test our second hypothesis, we compare efforts related to servitization to efforts made to implement other types of action programs. The questionnaire employed in our research contains the following action programs related to internal operations (respondents had to indicate on a 1-5 Likert scale the extent of efforts made to implement a given action program $-1=$ no effort, $5=$ high effort):

- A: implementation of action programs to increase the level of delegation and knowledge of employees (e.g. empowerment, training, autonomous teams)

- B: implementing continuous improvement programs through systematic improvement initiatives (e.g. kaizen, improvement teams)

- C: Restructuring manufacturing processes and layout to obtain process focus and streamlining (e.g. reorganizing for plant-within-plant, cellular layout)

- D: Undertaking actions to implement pull production (e.g. reducing batch sizes and setup time, using kanban systems)

- E: Quality improvement and control (e.g. TQM programs, six sigma projects, quality circles)

- F: Improving the productivity of machines and equipment (e.g. Total Productive Maintenance programs)

- G: Increasing design integration between product development and manufacturing (e.g. platform design, standardisation and modularisation)

- H: Increasing the organisational integration between product development and manufacturing (e.g. teamwork, job rotation and co-location)

- I: Active engagement for expanding the service offering to our customers (e.g. by investing in new service development)

- J: Active development of organizational capabilities needed to improve the service offering

- K: Improving the environmental performance of products and production processes (e.g. environmental management system, Product Life-Cycle Analysis, Design for Environment, environmental certification).

Among the listed action programs, the ones marked with I and $\mathrm{J}$ are related to servitization. The average effort of Hungarian manufacturing companies to implement various action programs is illustrated in Figure 4. 
Figure 4: The efforts of Hungarian manufacturing companies to implement action programs to improve internal operations

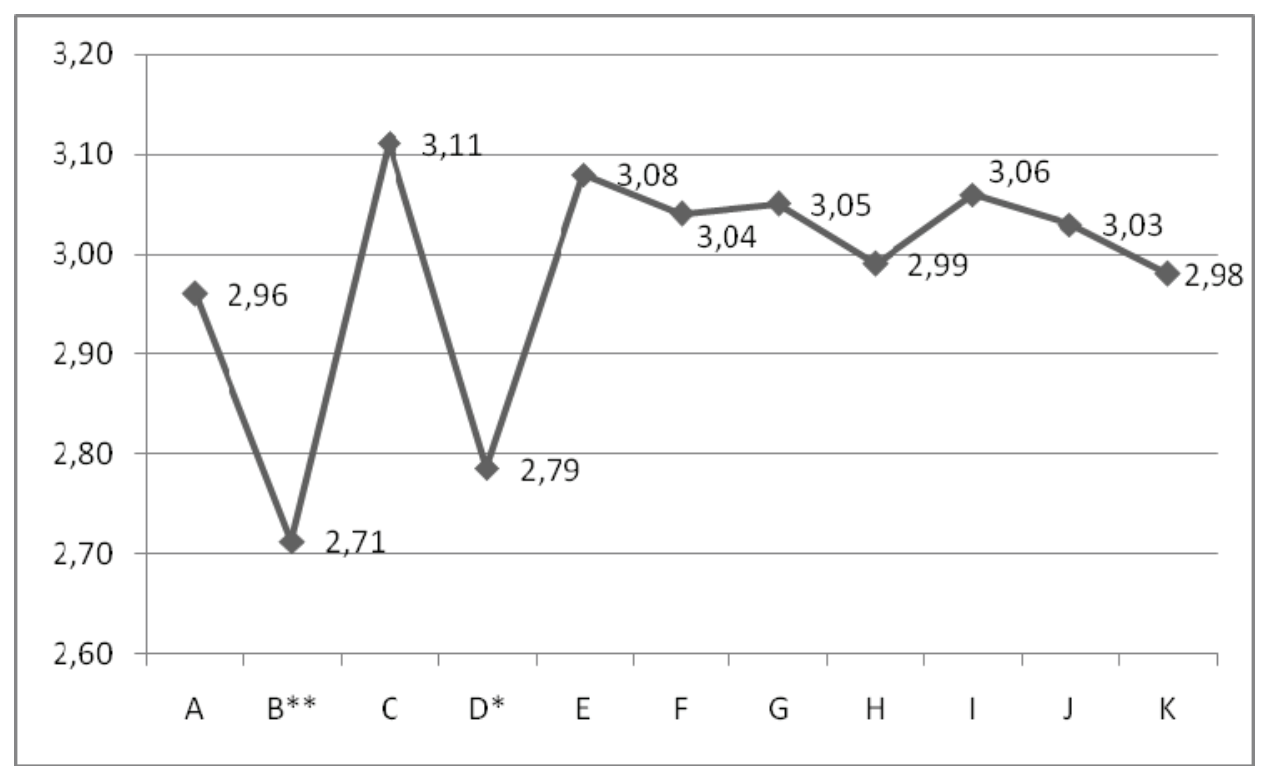

The difference between the effort to implement a given action program and servitization related action programs (I and J) is significant at $* * p=0.01$ level; at $* \mathrm{p}=0.05$ level.

According to Figure 4, Hungarian manufacturing companies invest at least as much effort into servitization related action programs as into other action programs (paired-samples t-tests at $\mathrm{p}=0.05$ level). Moreover, there are action programs, such as B (continuous improvement) and D (pull production), where efforts are significantly lower. These results mainly support our findings in the strategic section, since, on average, the effort to implement service related programs does not exceed the effort to implement other types of action programs. Thus, these findings support $H 2$.

In contradiction, however, we found no significant difference between the groups of "Servitized companies" and "Traditional manufacturers" in terms of the efforts made to implement servitization related action programs (ANOVA at $\mathrm{p}=0.05$ level). Thus, there seems to be no relation between the strategic and operational approach of servitization. These findings go against the main assumptions of strategic management literature, which argue that strategic objectives should drive activities on the operational level (e.g. Thompson/Martin, 2010). This contradiction can stem from the fact that on the strategic level we did not consider the difference between the wider and narrower meanings of customer services. On the other hand, the economic crisis can also explain this contradiction: even if some companies do not consider services strategically important, on the short run they can attempt to offer extra services to the few customers they could retain. However, it still remains questionable why companies with higher strategic emphasis on services ("Servitized companies") do not manage to make extra efforts to implement service related action programs on operational level. 
When analysing the main objective of new technology adoption at Hungarian manufacturing companies, - on average - the relationship between strategic and operational levels regarding services appears to be supported. On average, with no real intention to strategically emphasize services, manufacturing companies rarely use new technologies to develop new services. Results are summarized in Figure 5 (companies had to indicate on 1-5 Likert scales the main reasons of adopting new technologies in operations).

Figure 5: Objectives of implementing new technologies at Hungarian manufacturing companies

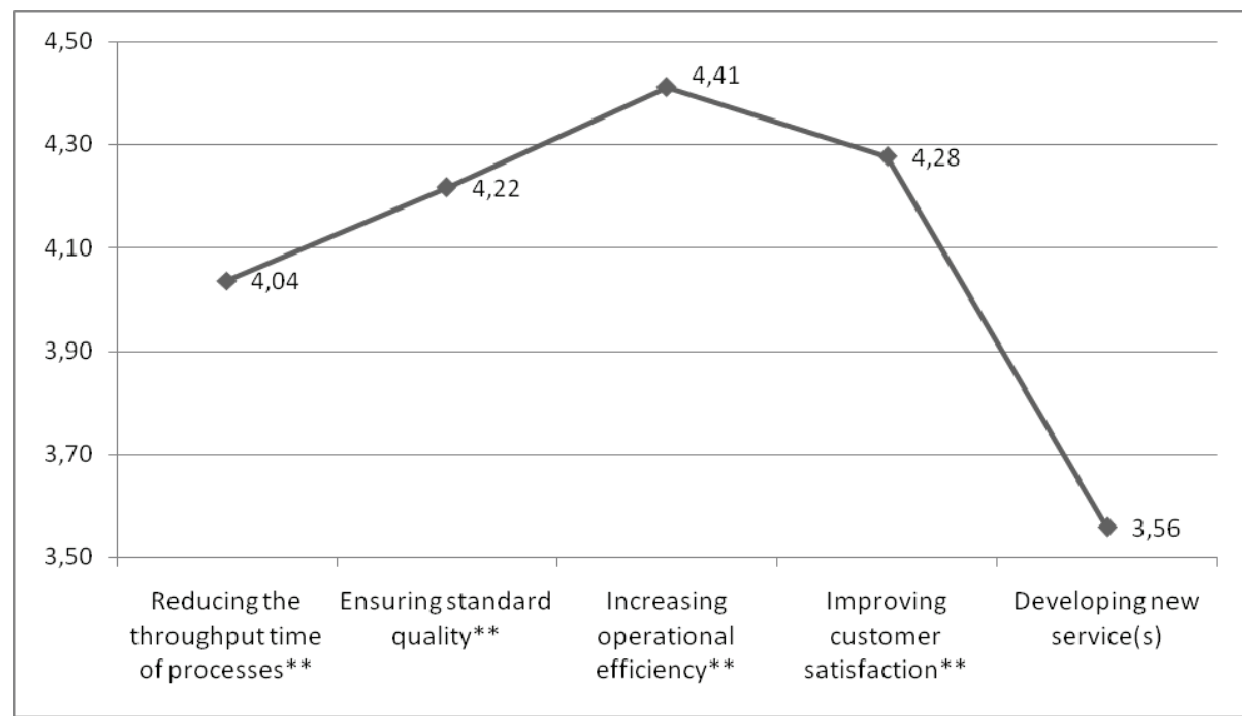

** The difference between the importance of a given objective and "Introducing new service(s)" is significant at $\mathrm{p}=0.01$ level

Figure 5 shows that implementing new technologies at Hungarian manufacturing companies starts rarely with the purpose of developing new services, which - from the point of view of new technology adoption - supports our second hypothesis. However, similarly to service related action programs we found no significant difference between "Servitized companies" and "Traditional manufacturers" in terms of using new technologies to develop new services (ANOVA at $\mathrm{p}=0.05$ level).

Summarizing the two results regarding the operational level, it can be stated that Hungarian manufacturing companies make average efforts to implement service related action programs, and these efforts are rarely supported by technology. Thus, $H 2$ can be accepted. However, we found no real connection between the strategic intent of companies to servitize, and actions on operational level that would support a service oriented strategy.

Moving on to $H 3 a$, we aim to test if the relationship between company size and servitization can be confirmed on our sample. The majority of articles in the servitization literature suggest that large companies are more likely to servitize, and most of these papers rely exclusively on studying large, renowned 
companies (e.g. Cohen et al. 2000; Davies 2004; Schmenner 2009; Martinez et al. 2010). However, the relationship between company size and servitization has rarely been tested empirically (Neely 2008). To carry out this analysis we first grouped companies (small, medium, large) according to the exact legal classification. Having these three groups, we tested if there is significant difference between them in respect of the strategic importance of services. For testing we used analysis of variance (ANOVA) with LSD post-hoc test, this latter being the most permissive post-hoc test and, therefore, the most sensitive to differences between groups. Results of our tests are summarized in Table 3.

Table 3: Relationship between company size and servitization

\begin{tabular}{|c|c|c|c|c|c|}
\hline \multirow[t]{2}{*}{$\begin{array}{l}\text { Company } \\
\text { size }\end{array}$} & \multirow[t]{2}{*}{$\begin{array}{l}\text { Number of } \\
\text { companies }\end{array}$} & \multirow{2}{*}{$\begin{array}{c}\text { Strategic } \\
\text { importance of } \\
\text { services }\end{array}$} & \multicolumn{3}{|c|}{$\begin{array}{l}\text { Significant difference } \\
(p=0.05)\end{array}$} \\
\hline & & & Small & Medium & Large \\
\hline Small & 84 & 0.992 & $\mathbb{Z}$ & - & - \\
\hline Medium & 14 & 0.922 & - & & - \\
\hline Large & 9 & 0.906 & - & - & \\
\hline
\end{tabular}

According to these results there is no significant difference between small, medium and large companies in the strategic importance of services. Moreover, although not significantly, small companies in our sample tend to be more service oriented than larger ones. Similar results have been obtained when the three groups were compared in terms of efforts to implement service related action programs. Consequently, $H 3 a$ is rejected.

A similar approach has been employed to test the relationship between ownership type and servitization $(H 3 b)$. Three groups were created based on the majority ownership of companies: domestic, foreign and state ownership. Since our sample contained only two companies with state ownership, they were excluded from further analyses. Thus, the following groups were developed:

- Domestic majority ownership (77 companies)

- Foreign majority ownership (23 companies)

Using analysis of variance (ANOVA) we examined if there are significant differences between the two groups in respect of the strategic and operational role of services. Results are summarised in Table 4. 
Table 4: Relationship between majority ownership and servitization

\begin{tabular}{|c|c|c|c|}
\hline & $\begin{array}{c}\text { Domestic } \\
\text { ownership }\end{array}$ & $\begin{array}{c}\text { Foreign } \\
\text { ownership }\end{array}$ & $\begin{array}{c}\text { Significance } \\
\text { of } \\
\text { difference }\end{array}$ \\
\hline \multicolumn{4}{|l|}{ Strategic level } \\
\hline Relative importance of services & 1.011 & 0.873 & 0.005 \\
\hline \multicolumn{4}{|l|}{ Operational level - action programs } \\
\hline $\begin{array}{l}\text { Our company actively engages in } \\
\text { expanding the service offering to } \\
\text { our customers }\end{array}$ & 3.04 & 2.83 & 0.120 \\
\hline $\begin{array}{l}\text { We are actively developing the } \\
\text { skills in the organization needed to } \\
\text { improve the service offering }\end{array}$ & 3.00 & 3.00 & 0.459 \\
\hline \multicolumn{4}{|c|}{ Operational level - the objective of using new technology } \\
\hline Developing new service(s) & 3.60 & 3.37 & 0.599 \\
\hline
\end{tabular}

** The difference between the two groups is significant at $\mathrm{p}=0.01$ level

Ownership has a significant impact only on the strategic importance of services. However, the difference between the two groups works in the opposite direction than expected. Companies with domestic majority ownership assign higher relative strategic importance to services than companies with foreign ownership. These results go against the mainstream assumption in the literature, and suggest that companies with domestic ownership may also choose the path of servitization. Therefore, $H 3 b$ has to be rejected.

To test $H 3 c$, we investigated if the percentage share of sales realized abroad in the total sales of each company differs significantly between the groups of "Servitized companies" and "Traditional manufacturers". The result of our variance analysis shows that there is no significant difference (ANOVA, F(1, $83)=.001, \mathrm{p}=.975$ ) between the two groups. On average, "Servitized companies" realize $42.68 \%$ of their sales from outside the country, while the same figure in case of "Traditional manufacturers" is $42.60 \%$. Consequently, $H 3 c$ has to be rejected.

A similar approach was used to test $H 3 d$. We investigated whether "Servitized companies" tend more to skip intermediaries (distributors, retailers) and are in a more direct contact with end-consumers than "Traditional manufacturers". The result of our variance analysis indicates that the percentage sales originating directly from end consumers (i.e. skipping intermediaries) does not differ significantly between the two groups of companies (ANOVA, $\mathrm{F}(1,88)=.029$, $\mathrm{p}=.865$ ). On average, "Servitized companies" realize $57.10 \%$ of their sales directly from selling to end-consumers, while the same figure in case of "Traditional manufacturers" is $58.50 \%$. Therefore, $H 3 d$ is rejected. 


\section{Business performance perspective}

Following the analysis of servitization on strategic and operational levels, the current subsection focuses on the impact of servitization on the financial performance of manufacturing companies. Based on our literature review, market share and profitability measures were included in our analysis. These indicators were frequently reported to be positively influenced by servitization (e.g. Wise/Baumgartner 1999; Mathieu 2001; Baines et al. 2009). Here, market share and profitability indicators were measured on perceptual scales. Companies had to rate their performance compared to the industry average in respect of market share, return on sales (ratio of net profit and sales), and return on investments (ratio of net profit and invested capital). These indicators are able to offer a relevant picture regarding business performance and are easy to compare across companies. Responses were measured on a 1-5 Likert scale $(1=$ performance is much below industry average, 3 = performance equals industry average, $5=$ much better performance than the industry average). Based on the three business performance indicators we aimed to investigate if a higher strategic level of servitization leads to higher financial results. For this purpose, the two groups of "Servitized companies" and "Traditional manufacturers" were used. Results of our analysis of variance (ANOVA) are summarized in Table 5.

Table 5: Relationship between servitization and financial performance

\begin{tabular}{|l|c|c|c|}
\hline & $\begin{array}{c}\text { Servitized } \\
\text { companies }\end{array}$ & $\begin{array}{c}\text { Traditional } \\
\text { manufacturers }\end{array}$ & $\begin{array}{c}\text { Significance } \\
\text { of difference }\end{array}$ \\
\hline Market share & 3.13 & 3.20 & 0.690 \\
\hline ROS & 3.15 & 3.00 & 0.355 \\
\hline ROI & 3.19 & 3.00 & 0.274 \\
\hline
\end{tabular}

Results of our analysis show that there is no real difference between the two groups in respect of the three business performance indicators. Although profitability indicators tend to be somewhat better in the case of servitized companies, the differences are not statistically significant. These results were cross-checked with absolute measures from the declared 2007 financial statements of the companies. Having the publicly available financial data, the following financial indicators were computed: return on sales, return on investment and return on assets (ratio of net profit and total assets). The analysis of absolute data (ANOVA at $\mathrm{p}=0.05$ level) also confirmed that there is no significant difference between the two groups of companies in terms of the computed profitability indicators.

Consequently, results of our analysis suggest that Hungarian manufacturing companies choosing the path of servitization are not yet able to capture its financial advantages. However, since the efforts to implement service related action programs are similar in the two groups, and none of the two groups places 
too much emphasis on hard investments in services (technology developments), it is not surprising that their financial efficiency is not different. In conclusion, while we acknowledge that there are several other servitization related factors (e.g. organizational structure, motivation systems) that may influence business performance, we suggest that in case of our sample a superior level of servitization in strategic terms does not necessarily lead to better business performance, if the strategic intent to servitize is not supported on operational level. Thus, $H 4$ has to be rejected.

\section{Discussion}

Our paper focuses on the servitization of manufacturing placing our study in a macro-environment that has received only limited attention in international research.

Our research shows that services do not generally play an important role in the operations strategy of Hungarian manufacturing companies. Thus, from a strategic point of view servitization cannot be considered a dominant phenomenon in our sample. While on average servitization does not seem to dominate, there are already several manufacturing companies that consider services as strategically important. In the same time, these companies place a significantly lower emphasis on selling prices than their non-servitized counterparts. These results are in concordance with international servitization literature: in less developed countries manufacturing companies choose the path of servitization less frequently (Neely 2008). Those who do, however, usually set higher selling prices; integrated solutions offered as a bundle of products and services represent a higher value-added for the customers and can be priced accordingly (Mathieu 2001; Correa et al. 2007; Gebauer/Fleisch 2007).

The average results on operational level seem to support strategic level findings. Our research shows that Hungarian manufacturing companies invest a similar level of effort in carrying out service related action programs as in implementing other types of action programs. In the same time, new technologies (Chase/Garvin 1989; Neely 2008) are only rarely used to support new service development. Thus, it seems that, on average, services do not have an outstanding importance, neither on strategic, nor on operational levels. However, when distinguishing between companies that place a strategic emphasis on services and those who do not, results at the operational level do not match our expectations: both groups of companies invest the same amount of effort in carrying out service related action programs, regardless of how important services are declared on the strategic level. This seemingly contradictory result might explain our findings regarding the business performance of these companies.

Another important contribution of our study is that we critically re-examined the relationship between servitization, on one hand, and company size, ownership, 
globalization of selling, and position of the company in the value chain, on the other hand. Results of our research suggest that there is no relationship between servitization and the control variables mentioned above. These results go against the frequently mentioned stereotype that large companies with foreign ownership or companies with more intensive presence on global markets are more likely to choose the path of servitization. Additionally, there seems to be no relationship between the position of companies in the value chain (closer or farther from end-consumers) and servitization. These findings call for further research in the field: scientific papers should also focus on the servitization of small and medium-sized, domestic companies, with lower presence on global markets. Additionally, our results suggest that integrated solutions are not only offered in the most downstream positions of the value chain (i.e. close to endconsumers). Thus, companies positioned more upstream in the value chain should also be considered in future servitization related studies.

Finally, from a business performance perspective, results of our study show that Hungarian manufacturing companies choosing the path of servitization are not yet able to harvest service related financial benefits (Wise/Baumgartner 1999; Baines et al. 2009). Although on average they have a somewhat higher profitability than traditional manufacturers, these differences are far from being statistically significant. The lack of outstanding effort in technological support, as well as the similar level of efforts to implement service related action programs might explain these results. Our findings suggest that without strong operational support, emphasizing services exclusively on the strategic level will not lead to higher business performance.

Literature offers several possible explanations on how the lack of clear operational support of servitization may undermine the success of this process. First, there are several internal "soft" factors reported as being serious barriers of efficient servitization. These factors include the internal cultural resistance against servitization (Oliva/Kallenberg 2003), the need to change employee mindsets and continuously adapt human resource management policies to the dynamic strategy of servitization (Raja et al. 2010), and the difficulties of creating an organization in which operations, technical research and development, service development, marketing and sales are addressed integrally (Windahl/Lakemond 2006; Storbacka 2011). Without strong operational commitment it is unlikely that manufacturing companies can overcome these initial barriers. Beyond the internal challenges described above, companies aimed at offering integrated business solutions also need to develop more intensive relational processes with customers (Tuli et al. 2007; Storbacka 2011). Manufacturing companies need to make substantial efforts on operational level to shift from a pure transaction-based relationship toward a more relationshipcentered view (Gulati/Kletter 2005; Bastl et al. 2009) aimed at a better understanding and fulfilment of customer needs. If the supplier's and buyer's 
perspective (Lindberg/Nordin 2008) on the value delivered do not match, the supplier is likely to fail in setting prices high enough to remain profitable in the solution business (Tuli et al. 2007). Moreover, several studies show that for a successful provision of integrated solutions companies have to focus not only on the relationship with customers, but on the relationships within the wider business network as well, including customers, suppliers, strategic partners, research institutes and governmental organizations (Gulati/Kletter 2005; Windahl/Lakemond 2006; Bastl et al. 2012). While these cooperation and integration issues can be stressed on a strategic level, clearly, without a substantial operational effort companies will fail to grasp the additional value that lies in these partnerships. Determining which of and to what extent the factors described above hinder manufacturing companies to harvest the financial benefits of servitization, and what actions have to be taken to successfully and efficiently provide integrated solutions to customers remains an important research priority related to the servitization of Hungarian manufacturing.

Notwithstanding the issues described above, nowadays companies face an extremely competitive environment. Devoting a somewhat higher attention to services, and investing in improvement programs on an average level is not enough to reach an outstanding performance and sustainable competitive advantage. Moreover, simultaneously paying average attention to several operational factors means paying real attention to none of them. This lack of any clear strategy and supportive operations is visible, and actually has strengthened during the economic crisis in Hungary.

\section{Conclusion}

The main objective of our paper was to reveal if the dominant characteristics of servitization accepted by the international literature are also valid in a less developed economic environment, i.e. at Hungarian manufacturing companies. Until now, servitization and the provision of integrated solutions by manufacturing companies from developing countries have received less attention in the literature. The hypotheses of our study were formed based on the generally accepted theses of the international servitization literature - referring mainly to developing economies. We approached servitization from strategic, operational and business performance perspectives.

In summary, our results revealed that servitization and the related solution-based thinking is not yet a dominant phenomenon in Hungary. Although some companies place higher strategic emphasis on services and implement some action programs that may help overcoming the barriers of servitization, there is no clear, synchronized focus on service provision on strategic and operational levels, and, thus, the expected financial advantages are not clearly visible yet. It is up to these companies to make a further step forward, and build a solid source of competitive advantage by strengthening both their strategic and operational 
commitment towards servitization. Further research should shed more detailed light on what actions have to be undertaken by Hungarian manufacturing companies to be able to harvest the financial benefits from servitization.

An important limitation of this study is that data gathering took place during the beginning phase of the economic crisis, which can distort the results discussed in the previous section. In an economic crisis companies may overemphasize the role of selling prices, aiming more at retaining the existing customer base than at realizing higher business performance from services. Moreover, in pursuing this primary objective, services may act as a free or relatively cheap add-on to maintain a certain level of product sales.

\section{References}

Alonso-Rasgado, T./Thompson, G./Elfström, B.-O. (2004): The design of functional (totalcare) products, Journal of Engineering Design, vol. 15, no. 6, 515-540.

Baines, T./Lightfoot, H./Benedettini, O./Kay, J. (2009): The servitization of manufacturing. A review of literature and reflection on future challenges, Journal of Manufacturing Technology Management, vol. 20, no. 5, 547-567.

Baines T./Lightfoot, H./Smart P. (2011): Servitization within manufacturing. Exploring the provision of advanced services and their impact on vertical integration, Journal of Manufacturing Technlogy Management, vol. 22, no. 7, 947-954.

Balaton, K. (2005): Attitude of Hungarian companies towards challenges created by EU accession, Journal for East European Management Studies, vol. 10, no. 3, 247-258.

Bastl, M./Johnson, M./Evans, E. (2009): Managing supply chains in extreme conditions: a conceptual framework for servitized environments, paper presented at the 16th EurOMA Conference, Gothenburg, Sweden.

Brax, S. (2005): A manufacturer becoming service provider - challenges and a paradox, Managing Service Quality, vol. 15, no. 2, 142-155.

de Burgos Jimenez, J./Cespedes Lorente, J.J. (2001): Environmental performance as an operations objective, International Journal of Operations \& Production Management, vol. 21 , no. $1,1553-1572$.

Chase R.B./Garvin, D.A. (1989): The service factory, Harvard Business Review, vol. 67, no. 4, 61-69.

Chikán, A. (2008): Vállalatgazdaságtan, Budapest: Aula Kiadó.

Chikán, A./Czakó E./Zoltayné, P. Z. (ed.) (2002): National Competitiveness in the Global Economy: The case of Hungary. Budapest: Akadémiai Kiadó, ISBN: 9630578670.

Cohen, M.A./Cull, C./Lee, H.L./Willen, D. (2000): Saturn's supply chain innovation: high value in after-sales services, Sloan Management Review, Summer, 93-101.

Cohen, M.A./Agrawal, N./Agrawal, V. (2006): Winning in the aftermarket, Harvard Business Review, May 2006, 129-138.

Correa, H.L./Ellram, L.M./Scavarda, A.J./Cooper, M.C. (2007): An operations management view of the services and goods offering mix, International Journal of Operations \& Production Management, vol. 27, no. 5, 444-463. 
Davies, A. (2004): Moving base into high-value integrated solutions: a value stream approach, Industrial and Corporate Change, vol. 13, no. 5, 727-756.

Davies, A./Brady, T./Hobday, M. (2006): Charting a path toward integrated solutions, MIT Sloan Management Review, vol. 47, no. 3, 39-48.

Demeter, K. (2009): Szolgáltatásmenedzsment Magyarországon a termelő és szolgáltató vállalatoknál, Vezetéstudomány, vol. 40, no. 2, 9-22.

Evans, J.R./Berman, B. (1987): Marketing, $3^{\text {rd }}$ edition, New York: Macmillan.

Frambach, R./Wels-Lips, I./Gündlach, A. (1997): Proactive product service strategies - an application in the European health market, Industrial Marketing Management, vol. 26, no. 4, 341-352.

Gebauer, H./Fleisch, E./Friedli, T. (2005): Overcoming the service paradox in manufacturing industries, European Management Journal, vol. 23, no. 1, 14-26.

Gebauer, H./Fleisch, E. (2007): An investigation of the relationship between behavioural processes, motivation, investments in the service business and service revenue, Industrial Marketing Management, vol. 36, no. 3, 337-348.

Grönroos, C. (1990): Service Management and Marketing: managing the moments of truth in service competition, Lexington Books.

Gulati, R./Kletter, D. (2005): Shrinking core, expanding periphery: the relational architecture of high-performing organizations, California Management Review, vol. 47, no. 3, 77104.

Hayes, R.H./Wheelwright, S.C. (1984): Restoring our competitive edge: competing through manufacturing, New York: Wiley and Sons.

Heskett, J.L./Sasser, W.E./Schlesinger, L.A. (1997): The service profit chain, New York: The Free Press.

Hill, T. (1993): Manufacturing strategy, $2^{\text {nd }}$ Edition, Basingstoke: Macmillan.

Johne, A./Storey, C. (1998): New service development: a review of the literature and annotated bibliography, European Journal of Marketing, vol. 32, no. 3/4, 184-251.

Johnson, M./Mena, C. (2008): Supply chain management for servitized products: a multiindustry case study, International Journal of Production Economics, vol. 114, no. 1, 27-39.

Kindström, D./Kowalkowski, C. (2009): Development of industrial service offerings: a process framework, Journal of Service Management, vol. 20, no. 2, 156-172.

Lay, G./Copani, G./Jäger A./Biege S. (2010): The relevance of service in European manufacturing industries, Journal of Service Management, vol. 21, no. 5, 715-726.

Leong, G.K./Snyder, D.L./Ward, P.T. (1990): Research in the process and content of manufacturing strategy, Omega, vol. 18, no. 2, 109-122.

Lindberg, N./Nordin F. (2008): From products to services and back again: Towards a new service procurement logic, Industrial Marketing Management, vol. 37, 292-300.

Martinez, V./Bastl, M./Kingston, J./Evans, S. (2010): Challenges in transforming manufacturing organisations into product-service providers, Journal of Manufacturing Technology Management, vol. 21, no. 4, 449-469. 
Mathe, H./Shapiro, R.D. (1993): Integrating service strategy in manufacturing company, London: Chapman \& Hall.

Mathieu, V. (2001): Product services: from a service supporting the product to a service supporting the client, Journal of Business and Industrial Marketing, vol. 16, no. 1, 3958 .

Matthing, J./Sanden, B./Edvardsson, B. (2004): New service development: learning from and with customers, International Journal of Service Industry Management, vol. 15, no. 4, 479-498.

Matthyssens, P./Vandenbempt, K. (2008): Moving from basic offerings to value-added solutions: strategies, barriers and alignment, Industrial Marketing Management, vol. 37, no. 3, 316-328.

Miller, J.G./Roth A.V. (1994): A taxonomy of manufacturing strategies, Management Science, vol. 40, no. 3, 285-304.

Neely, A. (2007): The servitization of manufacturing: an analysis of global trends, konferencia-előadás: 14th EurOMA Conference, Ankara, Turkey.

Neely, A. (2008): Exploring the financial consequences of the servitization of manufacturing, Operations Management Research, vol. 1, no. 2, 103-118.

Oliva, R./Kallenberg, R. (2003): Managing the transition from products to services, International Journal of Service Industry Management, vol. 14, no. 2, 160-172.

Pawar, K.S./Beltagui, A./Riedel, J.C.K.H. (2009): The PSO triangle: designing product, service and organization to create value, International Journal of Operations \& Production Management, vol. 29, no. 5, 468-493.

Raja, J.Z/Green, S.D./Leiringer, R. (2010): Concurrent and disconnected change programs: strategies in support of servitization and the implementation of business partnering, Human Resource Management Journal, vol. 20, no. 3, 258-276.

Reinartz, W./Ulaga, W. (2008): How to sell services more profitably?, Harvard Business Review, May 2008, 90-96.

Schmenner, R.W. (2009): Manufacturing, service, and their integration: some history and theory, International Journal of Operations \& Production Management, vol. 29, no. 5, 431-443.

Stock, J.R. and Lambert, D.M. (2001): Strategic Logistics Management, Boston: McGrawHill-Irwin.

Storbacka, K. (2011): A solution business model: capabilities and management practices for integrated solutions, Industrial Marketing Management, vol. 40, no. 5, 699-711.

Thompson, J./Martin, F. (2010): Strategic Management. Awareness \& change. $6^{\text {th }}$ Edition, South-Western Cengage Learning.

Tuli, K.R./Kohli, A.K./Bharadwaj, S.G. (2007): Rethinking customer solutions: from product bundles to relational processes, Journal of Marketing, vol. 71, 1-17.

Vandermerwe, S./Rada, J. (1988): Servitization of business: adding value by adding services, European Management Journal, vol. 6, no. 4, 314-324.

Ward, P.T./McCreery, J.K./Ritzman, L.P./Sharma, D. (1998): Competitive priorities in operations management, Decision Sciences, vol. 29, no. 4, 1035-1046. 
Windahl, C./Lakemond M. (2006): Developing integrated solutions: the importance of relationships within the network, Industrial Marketing Management, vol. 35, no. 7, 806-818.

Wise, R./Baumgartner, P. (1999): Go downstream. The new profit imperative in manufacturing. Harvard Business Review, September-October 1999, 133-141. 